\title{
Couples' provision of informal care for parents and parents-in-law: far from sharing equally?
}

\author{
URSULA HENZ*
}

\begin{abstract}
This study examines whether and how couples share the provision of informal care for their parents. Four waves of the British General Household Survey contain cross-sectional information about caring for parents and parents-in-law. Descriptive and multivariate analyses were conducted on 2214 couples that provided parent care. The findings emphasise married men's contribution to informal caring for the parental generation and at the same time demonstrate the limits of their involvement. Spouses share many parts of their care-giving but this arrangement is less common with respect to personal and physical care. The more care is required the more likely are people to participate in care for their parents-in-law. More sons-in-law than daughters-in-law provide care but, once involved, daughters-in-law provide on average more hours of care than sons-inlaw. Own full-time employment reduces both men's and women's caring for their parents-in-law, and men's caring drops further if their wife is not in the labour market. The findings suggest that daughters-in-law often take direct responsibility whereas sons-in-laws' care-giving depends more on their wives' involvement. Children-in-laws' informal care-giving might decrease in the future because of women's increasing involvement in the labour market and rising levels of nonmarital cohabitation in mid-life.
\end{abstract}

KEY WORDS - informal caring, filial responsibility, parents-in-law, intergenerational support, secondary carers, gender, employment.

\section{Introduction}

Women have traditionally provided most eldercare, but men's contribution has attracted increasing attention as part of the inquiry into the gendered division of household work. This research studies married men's and women's informal caring for parents and parents-in-law. Although single people have a higher propensity to become carers (Dautzenberg et al. 2000; Henz 2006; Johnson and Lo Sasso 2000), married parent carers

* Department of Sociology, London School of Economics, London, UK. 
outnumber single parent carers (Dwyer and Coward I99I; Office for National Statistics 2002; Stone, Cafferata and Sangl 1987). Whereas married women's contribution is frequently acknowledged, the role of married men in parent caring is often questioned: 'If a married man's own parents require care his wife is likely to provide the bulk of it, and where married men do provide informal care to an elderly parent living elsewhere, they have the added support of a wife to assist in caring and to service their own domestic needs' (Arber and Ginn 1991: 137). Past research, most of it based on US studies, has elaborated the key role that wives play in their husbands' caring. Horowitz $(1985 b)$ reported that wives more often provided care for their husband's parents than husbands provided for their parents-in-law. Gerstel and Gallagher (200I) observed that men were 'drawn into caring' by their wives; that is, men cared a lot if their wives cared a lot.

Other research on care-giving by couples has shown that couples directed more help to the wife's parents than the husband's parents (Lee, Spitze and Logan 2003; Shuey and Hardy 2003). Married men's care might, therefore, often be care as sons-in-law. According to past research, sons-in-law provided little of the day-to-day caring (Brody and Schoonover 1986) and were merely assisting their wives (Qureshi and Walker i989). When comparing sons-in-laws' and daughters-in-laws' caring, Horowitz's $(1985 b)$ results suggest a larger contribution from daughters-in-law whereas others found little difference between the amount of help that men and women provided to their parents-in-law in studies limited to co-resident care (Arber and Ginn I995 a) or to employed carers (Ingersoll-Dayton, Starrels and Dowler 1996). Another body of research that is relevant for assessing men's contribution to informal parent care has suggested that men's caring has been under-represented in many studies because they captured only a narrow range of care activities. Where research included a wide range of helping and caring activities, men's contribution has been more visible (Lee, Dwyer and Coward I993; Soldo, Wolf and Agree I990; Spitze and Logan I990; Stoller I983, 1990). Traditional male tasks demonstrated a higher male involvement than traditionally female tasks (Dwyer and Seccombe i99I). In addition, Matthews (1995, 1998) has reported cases where men downplay their own contribution to parent care.

The purpose of this research is to study couples' informal caring for their parents from two perspectives. The first part examines how the provision of different caring tasks varied with the gender of the care-giver and the care-recipient as well as with their kinship relation. The second part examines under which circumstances sons-in-law and daughtersin-law participated in caring. These questions are addressed by analysing 
British General Household Survey (GHS) data on 2,214 couples that cared for at least one parent at the time of the interview.

\section{Background}

Past studies have drawn a rather detailed picture of the caring behaviour of individuals (Arber and Ginn I995 $a$; Hirst 200I ; Parker I990). However, the type and amount of caring might differ depending on whether a single person provides help or whether there is a care-giver team like a couple, a pair of siblings, or even a wider care network (Keating et al. 2003; Scott and Wenger 1995). The framework of this study builds on past research about the division of care-giving between siblings and between spouses. Within couples one would expect a child-in-law to provide less care than a child because children are influenced by consanguinity (Kivett 1985) and by long-term commitments based on past reciprocities (Litwak I985).

\section{Gender roles}

The vital role of women in informal caring, and especially the more personal and domestic caring activities, has long been acknowledged (Arber and Ginn r995a; Horowitz I985a; Office for National Statistics I998). Caring is considered to be a crucial part of female gender identity, and gender roles play an important part in dividing caring tasks between relatives (Graham I983; Hequembourg and Brallier 2005). This implies that women are more committed to caring and that they have fewer 'legitimate excuses' for not providing care (Finch i989). The division of informal care between spouses should reflect these role differences. Because they can appeal to the traditional female role, it is easier for men to ask their wives for support with care for their parents, whereas gender roles make it more difficult for women to enlist their husbands in caring (Litwak i985). This leads to the first hypothesis:

Hi Daughters-in-law are more likely than sons-in-law to support their spouses in the care of their parents.

\section{Care-receiver's preferences}

Among the factors that influence care-receiver's preferences are emotional closeness, similarity of attitudes (Pillemer and Suitor 2006) and the quality of the relationship between the care-recipient and the potential carer (Matthews 1998). In addition, family members, including older parents, adopt cultural assumptions about what constitutes gender-appropriate 
behaviour (Matthews 1995). Especially for the more intimate types of caring, care-recipients might prefer a carer of the same gender (Arber and Ginn 1995a). Many studies have found evidence in support of such a 'cross-sex taboo' (Arber and Ginn i995 $a$; Lee, Dwyer and Coward I993; Pillemer and Suitor 2006; Stoller 1983), whereas no gender difference showed up in Horowitz's $(1985 b)$ research. Arber and Ginn found no support for their hypothesis that the cross-sex taboo might be weaker in relation to women caring for dependent men than the other way round (Arber and Ginn I995a). The cross-sex taboo can be contrasted with general hierarchies of preferences for carers as suggested by, for example, Dooghe (1992) or Qureshi and Walker (1989). In both hierarchies daughters and even daughters-in-law rank higher than sons, meaning that they are preferred to sons as carers. Based on these considerations one can formulate two competing hypotheses:

$\mathrm{H} 2 \mathrm{a}$ For the most intimate types of caring the carer is more likely to be a person of the same gender.

$\mathrm{H}_{2} \mathrm{~b}$ For the most intimate types of caring the carer is more likely to be female.

\section{Couples as care-giver teams}

If a couple provides care, they can arrange these tasks in different ways. The 'principle of substitution' (Shanas 1979) would imply that the majority of eldercare is assumed by one individual with other family members performing necessary tasks when the primary care-giver is not available (Shuey and Hardy 2003). This can be contrasted with the 'task-specific model', in which different groups of relatives are preferred for different tasks, including gendered preferences. In the research by Spitze and Logan (I990), different models applied to different caring tasks.

Studies of spouses as 'secondary helpers' have shown that they supplement rather than complement the role of the primary care-giver (Penrod et al. 1995; Tennstedt, McKinlay and Sullivan 1989), and that one spouse is usually the primary carer whereas the other spouse assists in caring. These observations present a static view of care-giving. One could, however, argue that caring arrangements adapt flexibly to the care needs of the elderly person. Two scenarios are possible, leading to two competing hypotheses. When caring by a primary carer gets more demanding and interferes with other areas of life, the spouse may step up his or her efforts to support and relieve the primary carer. This means that the spouse increases her or his caring hours along with the hours provided by the primary carer, and possibly even increases their share of caring hours. An alternative scenario would be that both spouses provide light caring 
duties together as part of their social lives, but when the care needs get heavier, one of them takes over the main burden. This would imply that the number of care hours of the secondary helper would stabilise and that his or her share of the total hours of care for the parent decreases. The two competing hypotheses can be summarised as follows:

$\mathrm{H}_{3}$ a The more care a couple provides the more one spouse specialises in caring.

$\mathrm{H}_{3} \mathrm{~b}$ The more care a couple provides the more equally they share the task.

\section{Employment}

Informal caring affects men's and women's employment in different ways (Arber and Ginn I995b). Even when carrying a rather heavy caring burden of at least 20 hours per week, men combined it more often than women with paid work, and among those who were in paid work, more men than women were working full-time (Office for National Statistics I998, Table 25). It was also more common among women than men to leave the labour market in connection with caring (Henz 2004), supporting observations that employment acts as a buffer that limits men's availability for caring (Stoller I983; Ungerson I987) but not women's (Stoller I983). In practice, this might mean that men obtain a higher level of support from their spouses than female carers do (Horowitz I985 $b$ ). If a couple has already been practising the traditional specialisation into market work and housework, it could be perceived as natural that the woman takes on the additional family-oriented task of caring. However, with the increasing rate of female labour-force participation, employment might become also a 'legitimate excuse' for women for not caring or for setting limits to their caring. This might be more so for daughters-in-law than for daughters because the expectations about their caring tend to be lower than for daughters. Women's increasing levels of employment might also put more pressure on men to provide care especially for their own parents. This could mean that men's full-time employment by itself ceases to be a legitimate excuse for not caring, but that the joint employment pattern of the couple needs to be considered.

Time-budget considerations suggest that part-time workers provide more informal care than full-time workers. Previous British studies have found, however, that part-time working women had the same propensity of becoming a carer as full-time working women (Henz 2006), nor was there a difference between part-time workers and full-time workers in leaving work when they started caring (Henz 2004, 2006). Part-time workers changed their working hours more flexibly in response to their 
caring commitments. These patterns might suggest that part-time work is a legitimate excuse for not caring, but that once involved, part-time workers provided more hours of care. These considerations can be summarised in three hypotheses:

$\mathrm{H}_{4}$ a Full-time working children-in-law provide less care than children-in-law who are not in the labour market.

$\mathrm{H}_{4} \mathrm{~b}$ Children-in-law provide more care if their spouses are working full-time.

$\mathrm{H}_{4 \mathrm{c}}$ Part-time working daughters-in-law are equally likely to be involved in caring as full-time working daughters-in-law, but on average they provide more hours of care.

\section{Co-residence}

Only a small and declining proportion of elderly British men and women live with their children (Falkingham and Grundy 2006), most of them with their daughters (Grundy 1992). As most personal care is provided within the household (Office for National Statistics 1998; Pickard 2002), one would expect couples to provide more intensive care to co-resident parents than to other parents. Doty, Jackson and Crown (1998) reported that coresidence of a female primary care-giver with the care-recipient increased the likelihood of obtaining help from other sources. They hypothesised that 'if a female primary care-giver ... wants to obtain more supplemental informal help from her husband ... she is most likely to obtain this help if she can bring the care-recipient into her home' (p. 34I). Similarly, Tennstedt, Crawford and McKinlay (I99I) found that co-residence increased sons' or sons-in-law's involvement in caring. This leads to the final hypothesis:

$\mathrm{H}_{5}$ Co-residence of the care-recipient is associated with higher levels of shared caring by the couple.

\section{Data and methods}

Data

The research used data from the 1985 , 1990, 1995 and 2000 waves of the British General Household Survey (GHS) (Office for National Statistics 2000; Office of Population Censuses and Surveys 1985, 1990, 1995), each providing a representative sample of the British adult population. In the four selected years, all adult household members were asked about informal caring at the time of the interview. Informal carers were identified as people who 'look after or give special help to someone who is sick, 
handicapped or elderly'. In 2000, the term 'disabled' was used instead of 'handicapped' and the qualification 'other than in a professional capacity' was added. Informal carers who only provided financial help or whose care-recipient lived in an institution have been excluded as well as, in the last two surveys, informal carers whose care-recipients had only temporary care needs.

The combined data set includes 20,335 couples. After excluding 39 cases in 1990 and 322 cases in 1985 for not providing the total number of carerecipients and an unclear case in 2000, 2,214 couples remained with at least one spouse providing informal care for a parent or parent-in-law at the time of the interview. Some further cases with missing values for the weekly hours of caring or the particular tasks performed were also excluded.

The large sample of caring couples allows comparatively detailed analyses of their caring patterns. It is possible to carry out separate analyses by gender and kinship. Other advantages of the data set are that both spouses reported their own caring, thus avoiding reporting bias from a single informant; and the rather broad selection of caring tasks, where traditionally male tasks were explicitly listed among the examples for 'helping with paperwork or financial matters' and 'other practical help', countered the linkage of women to most chores. The weaknesses of the GHS are that there is no general information about the care needs of parents and that information is incomplete about other care-givers for the same care-recipient.

\section{Variables}

Types of help and care provided. For each care-recipient, all GHS waves asked about eight types of help or care that the respondent 'usually' provided for the care-recipient: personal care; physical help; help with paperwork or financial matters; other practical help; keeping company; taking him/her out; giving medicines; keeping an eye on him/her to see he/she is all right. Arguably some tasks are not caring but just helping, for example 'keeping him/her company'. To identify the different dimensions of caring covered by the eight tasks, separate exploratory factor analyses for all eight gender and kinship-specific parent-child dyads were estimated (results not shown here). All factor analyses of his or her caring for a mother or a father identified two factors: intensive care (personal and physical care and giving medicines) and other care (all other tasks). Most factor analyses of his or her care for a mother-in-law or a father-in-law revealed three dimensions: intensive care (as above), medium care (practical help, paperwork and taking out) and light care (keeping company, keeping an 
eye on him/her) except women's care for a father-in-law where the intensive and the medium factors were merged. The factor analyses suggest that all eight tasks are part of the same construct of caring, and that there is a group of children-in-law who are only involved in the light forms of caring.

The hours of caring. Each carer has reported the number of weekly hours of caring separately for each care-recipient by choosing one of the following pre-coded time intervals: zero to four hours, five to nine hours, io to I9 hours, 20 to 34 hours, 35 to 49 hours, 50 to 99 hours, or Ioo or more hours. ${ }^{1}$ The intervals were the same in all surveys with two exceptions: the 1985 survey used the intervals 20 to 29 hours and 30 to 49 hours, and the 2000 survey used zero to Ig hours, the remaining intervals being the same as in the other surveys. For this analysis the hours of caring were computed as the mid-point of the chosen time interval, with one exception, and as IIo hours for the highest category of Ioo hours or more. The exception concerns the zero-to-I9-hours interval in the 2000 survey that was coded into 4.9 hours, which corresponds to the average caring hours for first and second dependants in the 1995 survey if the reported caring was between zero and ig weekly hours.

Measures of care needs. The multivariate models included two indicators that approximate the care-recipient's needs: the number of different caring tasks that the parent received from the couple and the number of hours of care that the natural child provided for the respective parent. The number of different caring tasks that the parent received from the couple is not constrained by the way the couple arranged its care-giving; single carers can provide as many tasks as the couple together. Both measures only capture care needs as far as they were met by the couple. Table 4 shows how the two measures varied with the way the couple divided the caring tasks.

\section{Further variables}

The multivariate models also control for calendar year with values from 0 (year 1985) to 3 (year 2000) to capture long-term trends in children-in-law's caring. The variables 'Wife's age' and 'Husband's age' give their ages in years. The dummy variable for marital status takes the value one for married couples and zero otherwise. The I985 survey did not collect information about non-marital cohabitation. Because the shares of cohabitants were low in the later years and had presumably been even lower in 1985 , the possible mistake of either misclassifying some cohabiting 
couples as married or of excluding cohabiting couples in 1985 should occur infrequently. The models also take husband's and wife's employment status into account. For men, any form of employment-part-time, full-time or self-employment - is compared to all other labour-market statuses. For women, the models distinguish between full-time work (more than 25 hours per week), part-time work (up to 25 hours per week) and not being employed or self-employed. Table I gives descriptive statistics for the independent variables in the multivariate models.

\section{Analyses}

To examine caring patterns by kinship status one needs to compare a son's care with that of a son-in-law for the same type of care-recipient, and to carry out corresponding comparisons for female carers. Same-sex preferences can be identified from differences in care provision of a daughter for a father and a mother or between her care for a mother-in-law and a father-in-law, and by the corresponding comparisons for sons.

The multivariate analyses include logit models for whether a son-in-law or a daughter-in-law, respectively, got involved in the care for a parent. The analyses for sons-in-law are based on all couples where at least one of her parents received any care from the couple, and correspondingly for daughters-in-law. Finally, for those sons-in-law and daughters-in-law who provided any care linear regression models were estimated to examine their hours of care. As the wives always provided care for their fathers-in-law if they lived in the same household and for almost all mothers-in-law if they lived in the same household, the corresponding variables were omitted from the logit model for women's caring.

\section{Results}

\section{Overall care-giving pattern}

Table 2 lists the different kinds of help and care provided by the couple to its parents. The first line gives the overall frequencies of elderly mothers and fathers who received any care. The woman's mother was most likely to receive any help followed by the husband's mother, the women's father and the husband's father. The pattern corresponds to known patterns of caring: mothers receive more care from children than fathers, mostly because fathers are more often cared for by their wives (Arber and Ginn I99I); other possible reasons include differences in filial obligation, health problems, or assertiveness in expressing care needs (Ingersoll-Dayton et al. I996). Table 2 also shows that the wife's parents received more help and 
T A в L E I. Descriptive statistics of independent variables

\begin{tabular}{|c|c|c|c|c|c|c|}
\hline \multirow[b]{2}{*}{ Variables } & \multicolumn{3}{|c|}{$\begin{array}{l}\text { All couples who } \\
\text { care for her parents }\end{array}$} & \multicolumn{3}{|c|}{$\begin{array}{l}\text { Couples where husband } \\
\text { cares for her parents }\end{array}$} \\
\hline & $\mathrm{N}$ & $\%$ & Mean & $\mathrm{N}$ & $\%$ & Mean \\
\hline Husband's age (years) & & & $49 \cdot 6$ & & & $5^{1} \cdot 3$ \\
\hline Married & I330 & 96 & & 580 & $9^{8}$ & \\
\hline Period 1985 & 336 & 24 & & $\mathrm{I} 44^{2}$ & 24 & \\
\hline I990 & 422 & 30 & & I96 & 33 & \\
\hline 1995 & 299 & 22 & & Io8 & $I 8$ & \\
\hline Her father received care & 429 & $3 I$ & & I84 & $3 I$ & \\
\hline Her mother received care & II 26 & $8 I$ & & 486 & $8_{2}$ & \\
\hline Both her parents received care & I63 & 12 & & 76 & 13 & \\
\hline Her father lived in same household & 19 & I & & I6 & 3 & \\
\hline Her mother lived in same household & 93 & 7 & & 65 & $I I$ & \\
\hline Types of care received by her father & & & I. 2 & & & I. 3 \\
\hline Types of care received by her mother & & & 3.6 & & & 4.0 \\
\hline Her hours of care for her parents & & & I6.o & & & I8.7 \\
\hline He not employed & 302 & 22 & & I4I & 24 & \\
\hline She not employed & 498 & 36 & & 215 & 36 & \\
\hline She worked part-time & $47 \mathrm{I}$ & 34 & & I83 & $3^{I}$ & \\
\hline \multirow[t]{2}{*}{ Total } & $\mathrm{I} 39^{2}$ & 100 & & 594 & 100 & \\
\hline & \multicolumn{3}{|c|}{$\begin{array}{l}\text { All couples who } \\
\text { care for his parents }\end{array}$} & \multicolumn{3}{|c|}{$\begin{array}{l}\text { Couples where wife } \\
\text { cares for his parents }\end{array}$} \\
\hline Wife's age (years) & & & $45 \cdot 3$ & & & $45 \cdot 9$ \\
\hline Married & 893 & 96 & & 530 & $9^{8}$ & \\
\hline Period 1985 & 262 & 28 & & I58 & 29 & \\
\hline I990 & 272 & 29 & & I69 & $3 I$ & \\
\hline I995 & I76 & 19 & & I03 & 19 & \\
\hline His father received care & 302 & 33 & & I79 & 33 & \\
\hline His mother received care & 735 & 79 & & 426 & 79 & \\
\hline Both his parents received care & I08 & 12 & & 64 & 12 & \\
\hline His father lived in same household & I4 & 2 & & I4 & 3 & \\
\hline His mother lived in same household & 34 & 4 & & 33 & 6 & \\
\hline Types of care received by his father & & & I. 2 & & & I. 3 \\
\hline Types of care received by his mother & & & $3 \cdot 2$ & & & $3 \cdot 4$ \\
\hline His hours of care for his parents & & & 9.2 & & & I0.0 \\
\hline He not employed & I79 & 19 & & 102 & 19 & \\
\hline She not employed & 315 & 34 & & I 88 & 35 & \\
\hline She worked part-time & 302 & 33 & & $\mathrm{I} 73$ & 32 & \\
\hline Total & 929 & 100 & & $54^{\mathrm{I}}$ & 100 & \\
\hline
\end{tabular}

care than the husband's parents, as has also been reported in US studies (Lee, Spitze and Logan 2003; Shuey and Hardy 2003). ${ }^{2}$

The wife will often be referred to as 'she' hereafter and mutatis mutandis the same convention is used for the husband. Turning to the shares of 'his' and 'her' caring that are given in the second to fourth row of Table 2, one can see that in the vast majority of cases the sons and daughters provided 
T A B L E 2. Couples' care provided for parents, by parent's gender and kinship status, and type of care

\begin{tabular}{|c|c|c|c|c|c|c|c|c|c|}
\hline Type of care & $\begin{array}{c}\text { Her } \\
\text { mother }\end{array}$ & $\begin{array}{c}\text { Her } \\
\text { father }\end{array}$ & $\begin{array}{c}\text { His } \\
\text { mother }\end{array}$ & $\begin{array}{c}\text { His } \\
\text { father }\end{array}$ & Type of care & $\begin{array}{c}\text { Her } \\
\text { mother }\end{array}$ & $\begin{array}{c}\text { Her } \\
\text { father }\end{array}$ & $\begin{array}{c}\text { His } \\
\text { mother }\end{array}$ & $\begin{array}{c}\text { His } \\
\text { father }\end{array}$ \\
\hline $\begin{array}{l}\text { Any care provided for ... } \\
\text { Only he cares } \\
\text { Only she cares } \\
\text { Both care }\end{array}$ & $\begin{array}{r}\text { II } 85 \\
3 \% \\
57 \% \\
40 \%\end{array}$ & $\begin{array}{r}448 \\
4 \% \\
57 \% \\
39 \%\end{array}$ & $\begin{array}{l}774 \\
42 \% \\
\text { II } \% \\
47 \%\end{array}$ & $\begin{array}{l}317 \\
42 \% \\
\text { I0 } \% \\
47 \%\end{array}$ & & & & & \\
\hline $\begin{array}{l}\text { Received personal care } \\
\text { Only from him } \\
\text { Only from her } \\
\text { From both }\end{array}$ & $\begin{array}{l}319 \\
\text { I } \% \\
90 \% \\
\text { I0 } \%\end{array}$ & $\begin{array}{l}68 \\
\text { I0 } \% \\
72 \% \\
\text { I } 8 \%\end{array}$ & $\begin{array}{l}\text { IO } 4 \\
24 \% \\
54 \% \\
22 \%\end{array}$ & $\begin{array}{l}52 \\
62 \% \\
13 \% \\
25 \%\end{array}$ & $\begin{array}{l}\text { Is kept company } \\
\text { Only by him } \\
\text { Only by her } \\
\text { By both }\end{array}$ & $\begin{array}{r}859 \\
4 \% \\
66 \% \\
30 \%\end{array}$ & $\begin{array}{r}290 \\
4 \% \\
64 \% \\
32 \%\end{array}$ & $\begin{array}{l}520 \\
4 \mathrm{I} \% \\
\mathrm{I} 6 \% \\
44 \%\end{array}$ & $\begin{array}{l}\text { I92 } \\
42 \% \\
\text { II \% } \\
47 \%\end{array}$ \\
\hline $\begin{array}{l}\text { Received physical care } \\
\text { Only from him } \\
\text { Only from her } \\
\text { From both }\end{array}$ & $\begin{array}{r}354 \\
5 \% \\
73 \% \\
22 \%\end{array}$ & $\begin{array}{r}86 \\
9 \% \\
55 \% \\
36 \%\end{array}$ & $\begin{array}{l}\mathrm{I} 52 \\
47 \% \\
20 \% \\
32 \%\end{array}$ & $\begin{array}{l}65 \\
57 \% \\
8 \% \\
35 \%\end{array}$ & $\begin{array}{l}\text { Is taken out } \\
\text { Only by him } \\
\text { Only by her } \\
\text { By both }\end{array}$ & $\begin{array}{r}837 \\
7 \% \\
57 \% \\
36 \%\end{array}$ & $\begin{array}{l}259 \\
\text { I0 \% } \\
56 \% \\
34 \%\end{array}$ & $\begin{array}{l}506 \\
47 \% \\
\text { I } 2 \% \\
41 \%\end{array}$ & $\begin{array}{r}\text { I } 8 \text { I } \\
48 \% \\
9 \% \\
43 \%\end{array}$ \\
\hline $\begin{array}{l}\text { Received help with paperwork } \\
\text { Only from him } \\
\text { Only from her } \\
\text { From both }\end{array}$ & $\begin{array}{r}709 \\
9 \% \\
67 \% \\
24 \%\end{array}$ & $\begin{array}{l}2 \text { II } \\
8 \% \\
66 \% \\
26 \%\end{array}$ & $\begin{array}{l}472 \\
6 \mathrm{I} \% \\
\mathrm{I} 4 \% \\
25 \%\end{array}$ & $\begin{array}{l}\mathrm{I} 4 \mathrm{I} \\
66 \% \\
\mathrm{I} 2 \% \\
22 \%\end{array}$ & $\begin{array}{l}\text { Is given medicine } \\
\text { Only by him } \\
\text { Only by her } \\
\text { By both }\end{array}$ & $\begin{array}{r}270 \\
2 \% \\
81 \% \\
17 \%\end{array}$ & $\begin{array}{c}71 \\
3 \% \\
79 \% \\
18 \%\end{array}$ & $\begin{array}{l}\text { II } 8 \\
44 \% \\
27 \% \\
29 \%\end{array}$ & $\begin{array}{l}39 \\
4 \mathrm{I} \% \\
26 \% \\
33 \%\end{array}$ \\
\hline $\begin{array}{l}\text { Received other practical help } \\
\text { Only from him } \\
\text { Only from her } \\
\text { From both }\end{array}$ & $\begin{array}{r}\text { IOI3 } \\
5 \% \\
6 \mathrm{I} \% \\
35 \%\end{array}$ & $\begin{array}{r}377 \\
5 \% \\
62 \% \\
33 \%\end{array}$ & $\begin{array}{l}659 \\
43 \% \\
16 \% \\
41 \%\end{array}$ & $\begin{array}{l}248 \\
40 \% \\
17 \% \\
42 \%\end{array}$ & $\begin{array}{l}\text { Is kept an eye on } \\
\text { Only by him } \\
\text { Only by her } \\
\text { By both }\end{array}$ & $\begin{array}{r}894 \\
4 \% \\
63 \% \\
33 \%\end{array}$ & $\begin{array}{r}330 \\
4 \% \\
6 \mathrm{I} \% \\
35 \%\end{array}$ & $\begin{array}{l}59 \mathrm{I} \\
43 \% \\
\text { I } 2 \% \\
44 \%\end{array}$ & $\begin{array}{l}230 \\
44 \% \\
\text { II \% } \\
45 \%\end{array}$ \\
\hline
\end{tabular}

Source: GHS 1985, 1990, I995, 2000 own calculations.

Note: The sample size was 2,2I4 couples. 
care for their own parents, and that it was quite common for both spouses to be involved in caring for the same care-recipient. For example, in about 4o per cent of all cases where her mother or father received care from the couple, both spouses were involved, compared to 47 per cent in the case of his parents. If his parents received any help, only $4^{2}$ per cent of the concerned sons were sole carers in the couple compared to 57 per cent of women who were sole carers for her parents. In a few couples, only the child-in-law provided care for the parent.

The results show that when a couple cared for his parents, $\left(\mathrm{IOO}^{-}-42=\right) 5^{8}$ per cent of daughters-in-law were involved compared to $\left(\mathrm{IOO}^{-57}=\right) 43 \mathrm{per}$ cent of sons-in-law who were involved in the care for her parents. One could, therefore, conclude that daughters-in-law provided more care than sons-in-law, but this might not be true because more couples provided care for the wife's parents. Altogether, 702 sons-in-law provided care compared to 630 daughters-in-law (no table). Most couples cared for only one parent at the time of the interview: of the 2,2I4 couples, eight cared for all four parents at the time of the interview, 47 for three, 388 for two and I,77I for just one parent.

\section{Couples division of single caring tasks}

The lower part of Table 2 reports the frequencies and the caring arrangements for the eight different tasks. For all parents and parents-in-law, personal care was the least common type of care together with 'giving medicines'. More common was receiving physical care, help with paperwork, being taken out, being kept company, being 'kept an eye on' and, most frequently, receiving other practical help. The most striking deviation from the general pattern of couples' caring was with personal care. For this, joint caring was the least common among all the tasks and the gender-specific bias was strongest: among those elderly people who received personal care, the majority got it from a woman; only for their own fathers were men the primary providers of personal care (in the couple). A relatively high share of sons-in-law provided personal care for their wives' fathers without any involvement from her. Altogether the figures display a propensity for the daughter to provide personal care for her parents and a propensity towards same-sex provision of personal care for the husband's parents.

A pattern similar to personal care appears also for physical care except that the men were more often than their wives involved in the physical care of their parents, and that more couples carried out the task together. Delivery of help with paperwork was the most gender-neutral of all tasks; in about two-thirds of the cases it was delivered by the son or daughter, 


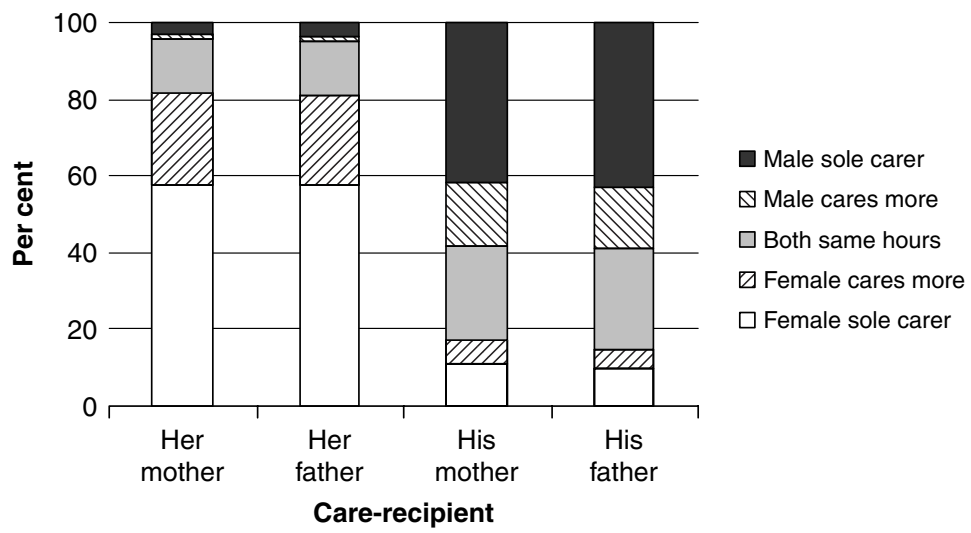

Note: The classification of care sharing is based on comparisons of spouses' hours of care.

Figure I. Distribution of care sharing by type of parent.

respectively, with relatively little sharing between the couple. The four most frequent types of help - other practical help, keeping company, taking out and keeping an eye on the elderly person - were shared to a higher extent; the percentages were in the low to mid-thirties for her parents and in the low to mid-forties for his parents. Women were more often the sole provider of the tasks to their parents (around 6o per cent) than were men were to their parents (40 per cent to $4^{8}$ per cent). Women overwhelmingly had the sole responsibility for giving medicines to their parents whereas the provision was more mixed for the husband's parents.

\section{Husband's and wife's hours of caring}

When comparing husband's and wife's hours of caring for a specific parent, one can distinguish: couples where both cared for about the same number of hours; couples where both spouses cared but one provided more hours than the other; and couples where only one spouse looked after the parent. Figure I shows that when both spouses provided care for the same person, they typically either shared equally or the child put in more hours. Table 3 presents the hours of care by a child-in-law in relation to the hours provided by the natural child. The first row gives the childin-law's hours of care when the natural child did not provide any care for the parent. On average this amounted to I4 hours of care by the sonin-law and i 3 hours of care by the daughter-in-law. From these cases one can see that women who were sole carers for their husbands' parents were on average less involved in the labour market than wives in other caring couples, and that women who left the care of their parents to their 
T А в L E 3. Average hours of caring for in-laws by hours of caring by natural child

\begin{tabular}{|c|c|c|c|c|c|c|c|c|}
\hline $\begin{array}{l}\text { Hours } \\
\text { cared by } \\
\text { daughter/ } \\
\text { son for } \\
\text { her/his } \\
\text { parents }\end{array}$ & $\begin{array}{c}(2) \\
\text { Mean } \\
\text { hours } \\
\text { males } \\
\text { cared for } \\
\text { their } \\
\text { parents- } \\
\text { in-law }\end{array}$ & (3) & $\begin{array}{c}\text { Share of } \\
\text { males } \\
\text { providing } \\
\text { care for } \\
\text { parents-in-law } \\
\%\end{array}$ & $\begin{array}{c}(5) \\
\text { Mean } \\
\text { hours } \\
\text { males } \\
\text { cared for } \\
\text { parents- } \\
\text { in-law; } \\
\text { carers } \\
\text { only }^{1}\end{array}$ & $\begin{array}{c}(6) \\
\text { Mean } \\
\text { hours } \\
\text { females } \\
\text { cared for } \\
\text { their } \\
\text { parents- } \\
\text { in-law }\end{array}$ & (7) & $\begin{array}{c}(8) \\
\text { Share of } \\
\text { females } \\
\text { providing } \\
\text { care for } \\
\text { parents- } \\
\text { in-law } \\
\%\end{array}$ & $\begin{array}{c}(9) \\
\text { Mean } \\
\text { hours } \\
\text { females } \\
\text { cared for } \\
\text { parents- } \\
\text { in-law; } \\
\text { carers } \\
\text { only }^{2}\end{array}$ \\
\hline o & I 4.4 & 37 & IOO & I 4.4 & I 2.7 & 94 & 100 & I 2.7 \\
\hline $\mathrm{I}-9$ & I. 7 & 768 & $3^{6}$ & $4 \cdot 7$ & 3.6 & 623 & 49 & $7 \cdot 3$ \\
\hline IO-I9 & 4.I & 304 & 45 & 9.I & 8.9 & I 34 & 63 & I 4.2 \\
\hline $20-29$ & $5 \cdot 9$ & I 26 & 44 & I $3 \cdot 3$ & I8.6 & 44 & 70 & 26.4 \\
\hline $3^{0-}-39$ & 6.9 & 40 & 45 & I9. 6 & I9. 3 & I9 & 53 & 36.6 \\
\hline $4^{\circ}-59$ & I 2.4 & 64 & $5^{2}$ & $24 . \mathrm{I}$ & 44.6 & I3 & 77 & $5^{8.0}$ \\
\hline $6 o-99$ & I 5.0 & 33 & 64 & 23.6 & $5^{0.8}$ & IO & 80 & $63 \cdot 4$ \\
\hline $\mathrm{IOO}+$ & $3^{0.2}$ & 34 & 68 & $44 \cdot 7$ & $99 \cdot 4$ & 4 & IOO & $99 \cdot 4$ \\
\hline Mean & 4.6 & & & I0.7 & $7 \cdot 7$ & & & I $3 \cdot 3$ \\
\hline Total & & I 406 & & 602 & & 94I & & 547 \\
\hline
\end{tabular}

Notes: I. These means are based only on sons-in-law who provided care. 2 . These means are based only on daughters-in-law who provided care.

husbands were often in poor health. The remaining rows of Table 3 specify children-in-law's contribution when their spouse also provided care for the parent. Column 2 shows that husbands' hours of care for their parents-in-law increased along with their wives' hours of care. For example, when the daughter cared 6o to 99 hours for her parents, the husband provided on average $\mathrm{I} 5$ hours of care. Similarly, according to column 6, wives' hours of care for their parents-in-law increased according to their husbands' hours; when the son provided 6o to 99 hours of care to his parents, his wife provided on average $5 \mathrm{I}$ hours. As the example shows, sons-in-laws' contributions were more modest than those of daughters-inlaw. The average hours of care in columns 2 and 6 depend both on the share of children-in-law who provided any care and the hours of care by those who were involved in caring. Columns 4 and 8 give the shares of husbands and wives, respectively, who provided care for their parents-inlaw. For both husbands and wives, the likelihood of their involvement increased with the hours of care by the spouse; for sons-in-law from about one-third to two thirds, and for daughters-in-law from about half to all. Columns 5 and 9 give the average hours by children-in-law who actually provided care, both displaying considerably higher caring hours than columns 2 and 6. Most strikingly, daughters-in-law who provided care for their parents-in-law more or less matched their husbands' caring hours. 
The division of caring tasks

The first four columns of Table 4 show to what extent spouses' caring overlaps. As seen earlier, the most common caring arrangement was caring by the natural child without any contribution from the spouse. The next most common arrangement was that the couple carried out all caring tasks together; nearly every fifth couple that cared for one of the husband's parents and every seventh couple that cared for one of the wife's parents shared all tasks. Another seven to io per cent of couples shared all tasks but one. A rather large group of couples that cared for his parents shared some tasks but each spouse had additional tasks that were not shared. This arrangement was less common in caring for her parents, in which it was more common that the couple shared some tasks and the wife carried out some additional tasks, especially when caring for her mother. The only differences between caring arrangements for mothers and fathers was that when caring for fathers it was less likely that a couple shared some tasks and only the woman carried out further tasks.

The second and third sections of Table 4 show how the division of caring tasks was related to the number of hours provided by the couple. On average, sole carers provided fewer hours and tasks than when the spouse was involved except for women who cared for their mothers: these women performed on average as many tasks as when both spouses shared all tasks. One can also see that the woman's mother received more help than other parents. ${ }^{3}$

\section{Multivariate analyses of child-in-laws' caring}

Having explored the extent to which couples shared their parent care, one would like to know what distinguished couples that jointly looked after a parent from sole-carer couples. Columns 2 and 3 of Tables 5 and 6 give the results from logit models that compare couples where the child-in-law was caring with those where only the natural child provided care. They indicate that older husbands were more likely to participate in the care for their parents-in-law, whereas there was no age effect for daughters-in-law. The odds of the child-in-law providing care were twice as high amongst the married as against the unmarried couples. Whether the child-in-law participated in caring did not depend on the gender of the parent. Having a parent living in the same household strongly increased the sons-in-law's odds of being involved in their care. As virtually all daughters-in-law were involved in caring for their parents-in-law if they lived in the same household, the corresponding variables were not included in the models. The more types of help the parent received, the more likely it was that the child-in-law contributed to the caring. In other words, the greater the care 
T A B L E 4. Informal care provided by the couple: division of their tasks, mean hours of care, and mean number of different tasks by caring arrangement

\begin{tabular}{|c|c|c|c|c|c|c|c|c|c|c|c|c|}
\hline \multirow[b]{2}{*}{ Care-giver(s) } & \multicolumn{4}{|c|}{ Percentage caring for ... } & \multicolumn{4}{|c|}{ Mean care hours for ... } & \multicolumn{4}{|c|}{ Mean number of different tasks provided for ... } \\
\hline & $\begin{array}{l}\text { Her } \\
\text { mother }\end{array}$ & $\begin{array}{l}\text { Her } \\
\text { father }\end{array}$ & $\begin{array}{c}\text { His } \\
\text { mother }\end{array}$ & $\begin{array}{l}\text { His } \\
\text { father }\end{array}$ & $\begin{array}{l}\text { Her } \\
\text { mother }\end{array}$ & $\begin{array}{l}\text { Her } \\
\text { father }\end{array}$ & $\begin{array}{l}\text { His } \\
\text { mother }\end{array}$ & $\begin{array}{l}\text { His } \\
\text { father }\end{array}$ & $\begin{array}{c}\text { Her } \\
\text { mother }\end{array}$ & $\begin{array}{l}\text { Her } \\
\text { father }\end{array}$ & $\begin{array}{c}\text { His } \\
\text { mother }\end{array}$ & $\begin{array}{l}\text { His } \\
\text { father }\end{array}$ \\
\hline Female only & 57 & 57 & II & IO & I3 & IO & I3 & 6 & 4. I & 3.5 & $3 \cdot 7$ & 2.4 \\
\hline Male only & 3 & 4 & $4^{2}$ & $4^{2}$ & 9 & I4 & 7 & 7 & $3 \cdot 4$ & 2.5 & $3 \cdot 5$ & $3 \cdot \mathrm{I}$ \\
\hline All tasks shared & I4 & I5 & I9 & I9 & 24 & 20 & 20 & I6 & 4.I & 3.7 & 4. I & 3.6 \\
\hline All tasks shared but one ${ }^{1}$ & 7 & 9 & IO & 9 & $2 \mathrm{I}$ & 28 & 27 & 36 & 4.6 & $4 \cdot 3$ & $4 \cdot 4$ & 4.6 \\
\hline Shared and he rest ${ }^{1}$ & I & o & o & o & 44 & - & IO & 5 & $5 \cdot 4$ & - & 3.0 & 4.0 \\
\hline Shared and she rest ${ }^{1}$ & $\mathrm{I} 2$ & 7 & 3 & I & 33 & 22 & 25 & 79 & 6.1 & $5 \cdot 9$ & $5 \cdot 5$ & 6.0 \\
\hline Shared and both separate & 5 & 6 & I4 & I6 & $3^{2}$ & 24 & $2 \mathrm{I}$ & 24 & $5 \cdot 7$ & $5 \cdot 5$ & $5 \cdot 3$ & $5 \cdot 3$ \\
\hline None shared, all separate & I & 2 & I & 2 & $2 \mathrm{I}$ & 20 & IO & 23 & 3.8 & $3 \cdot 4$ & $3 \cdot 6$ & 3.2 \\
\hline Mean & & & & & I8.8 & 14.9 & $14 \cdot 7$ & 14.8 & $4 \cdot 4$ & 3.8 & 4.0 & 3.7 \\
\hline $\mathrm{N}$ & $I I 78$ & $44 I$ & 766 & $3^{12}$ & 1178 & $44 I$ & 766 & $3^{12}$ & 1178 & $44 I$ & 766 & $3^{12}$ \\
\hline
\end{tabular}

Notes: I. If a couple shared one or several tasks and a single additional task was provided by one of the spouses, it is classified as 'All shared but one'. 
T A B L E 5. Husband's involvement in caring for his parents-in-law: results from a logit model for his caring and a linear regression of his hours of care

\begin{tabular}{|c|c|c|c|c|}
\hline & \multicolumn{2}{|c|}{$\begin{array}{l}\text { Logit: He cares } \\
\text { for parent-in-law }\end{array}$} & \multicolumn{2}{|c|}{$\begin{array}{l}\text { Linear regression: } \\
\text { His hours of care }\end{array}$} \\
\hline & Odds-ratio & Wald & $\mathrm{b}$ & $\mathrm{t}$ \\
\hline Constant & $0.06 * *$ & $39 \cdot 6 \mathrm{I}$ & 6.40 & 1.26 \\
\hline Calendar year & 0.99 & 0.08 & 0.13 & 0.24 \\
\hline Husband's age & $\mathrm{I} .02 * *$ & II. 67 & -0.05 & -0.75 \\
\hline Married & $2.30^{*}$ & 6.29 & I.99 & $0.5^{\mathrm{I}}$ \\
\hline Her father received care & 0.66 & I. 32 & 0.04 & O.OI \\
\hline Both her parents received care & 0.78 & 0.85 & $4 \cdot 95$ & I. 78 \\
\hline Her father lived in same household & $6.45^{* *}$ & $7 \cdot 5^{6}$ & $3 \cdot 4^{2}$ & 0.84 \\
\hline Her mother lived in same household & $3.05^{* *}$ & $\mathrm{I} 5.92$ & 8.10** & $3 \cdot 5^{6}$ \\
\hline Number of care types received by her father & I. $36^{* * *}$ & 21.87 & $-0.3^{8}$ & -0.60 \\
\hline Number of care types received by her mother & I. $2 \mathrm{I}^{* *}$ & $25 \cdot 15$ & -0.46 & $-\mathrm{I} . \mathrm{I} 2$ \\
\hline Wife's hours of care for her parents/ıo & 0.94 & $2.7 \mathrm{I}$ & $2.70^{* *}$ & 8.87 \\
\hline Husband not employed & I.09 & 0.28 & $7.6 \mathrm{I}^{* *}$ & 4.68 \\
\hline Wife not employed & $0.68^{*}$ & 6.14 & $-4 \cdot 3^{8 * *}$ & $-2.7 \mathrm{I}$ \\
\hline Wife worked part-time & $0.68 * *$ & 7.00 & $-0.4^{6}$ & $-0.3 \mathrm{I}$ \\
\hline $\mathrm{N}$ & I392 & & 594 & \\
\hline Chi-squared statistic & I38.I & & & \\
\hline Degrees of freedom & $\mathrm{I} 3$ & & & \\
\hline Adjusted $R^{2}$ & & & 0.25 & \\
\hline
\end{tabular}

Significance levels: $* * p<0.01, * p<0.05$.

needs - as indexed by the number of care tasks performed - the more likely it was that joint caring occurred. The hours of caring by the natural child had no additional influence on whether the child-in-law was involved. Women provided care for their husband's parents irrespective of their own or their husband's employment status. This differs from men who were more likely to be involved in caring for their parents-in-law if their wives worked full-time.

The last two columns in Tables 5 and 6 give the results of the linear regression models for the hours of care provided by the son-in-law and the daughter-in-law, respectively, if they provided any care for a parentin-law. There were no significant differences in the hours of care by calendar year, age, marital status, or the gender of the care-recipient. If the parent-in-law lived in the same household as the couple, the hours of care by the daughter-in-law increased on average by over 30 hours per week. Also sons-in-law provided significantly more care for the wife's mother if she lived in the same household, but the increase was more modest than the corresponding increase for daughters-in-law. The husband's care hours for his father-in-law did not increase significantly if the fatherin-law lived in the same household. Furthermore, the caring hours of 
T A B L E 6. Wife's involvement in caring for her parents-in-law: results from a logit model for her caring and a linear regression of her hours of care

\begin{tabular}{|c|c|c|c|c|}
\hline & \multicolumn{2}{|c|}{$\begin{array}{l}\text { Logit: She cares } \\
\text { for parent-in-law }\end{array}$} & \multicolumn{2}{|c|}{$\begin{array}{l}\text { Linear regression: } \\
\text { Her hours of care }\end{array}$} \\
\hline & Odds-ratio & Wald & b & $\mathrm{t}$ \\
\hline Constant & $0.10^{* *}$ & $19 \cdot 32$ & -4.66 & -0.89 \\
\hline Calendar year & 0.90 & 2.82 & 0.34 & $0.6 \mathrm{I}$ \\
\hline Wife's age & I.OI & 2.90 & $-0.0 \mathrm{I}$ & -0.14 \\
\hline Married & $2.7 \mathrm{I}^{*}$ & 6.46 & I.95 & 0.46 \\
\hline His father received care & I. 74 & 2.13 & $-\mathrm{I} .79$ & $-0.5^{2}$ \\
\hline Both his parents received care & $0.35^{* *}$ & II.I5 & -0.23 & -0.08 \\
\hline His father lived in same household & & & $37.19^{* *}$ & $9 \cdot 17$ \\
\hline His mother lived in same household & & & $30.53^{* *}$ & II. 26 \\
\hline Number of care types received by his father & I. $26^{* *}$ & IO.I4 & I. $56^{*}$ & 2.59 \\
\hline Number of care types received by his mother & I. $36^{* *}$ & $36.4^{2}$ & I.I3* & 2.54 \\
\hline Husband's hours of care for his parents/Io & 0.99 & 0.02 & $5.09^{* *}$ & II.94 \\
\hline Husband not employed & 0.78 & I.6I & -0.74 & -0.44 \\
\hline Wife not employed & I.04 & 0.05 & $7.20^{* *}$ & 4.80 \\
\hline Wife worked part-time & 0.95 & 0.10 & I. 32 & 0.90 \\
\hline $\mathrm{N}$ & 929 & & $54 \mathrm{I}$ & \\
\hline Chi-squared statistic & 78.2 & & & \\
\hline Degrees of freedom & II & & & \\
\hline Adjusted $R^{2}$ & & & 0.58 & \\
\hline
\end{tabular}

Significance levels: $* * p<0.01, * p<0.05$.

daughters-in-law were higher the greater the care needs of the older person: for each additional task performed for a parent-in-law they increased their caring activity by more than one hour. Children-in-law also increased their caring hours in line with their spouses' hours of caring: for every hour the daughter cared for her parent, the son-in-law increased his caring by about 15 minutes, ${ }^{4}$ and for each hour the son cared for his parents, the daughter-in-law increased her caring on average by about half-an-hour. ${ }^{5}$

The person's labour-market status had a strong influence on a childin-law's hours of caring. Both sons-in-law and daughters-in-law cared for significantly more hours if they were not employed; in both cases the average hours of care increased by more than seven hours. Part-time working daughters-in-law provided about the same number of hours as full-time working daughters-in-law. Furthermore, a son-in-law's caring also depended on his wife's employment status: if she was not (self-)employed, the son-in-law provided about four hours less care than if she was working full-time or part-time.

If the employment effects are examined more closely, one finds that the effects of employment on the child-in-law's caring were actually related to 
the spouse's caring hours: the more hours of care the spouse provided, the larger was the increase in the child-in-law's caring if he or she was not in the labour market, and the larger was the reduction in the son-in-law's hours of care if his wife was not in the labour market.

\section{Discussion}

\section{Couples as care-giver teams}

The main concern of this study was the division of the care of parents between spouses. It has been shown that many couples shared the care for their parents, and even that many couples provided all the tasks together. Sons and daughters provided care for their parents without support of the spouse, especially when the care needs were limited. The higher the care needs of the parents, the more often children-in-law joined in and the more hours they provided. However, sons-in-laws' engagement remained lower than that of daughters-in-law. Those daughters-in-law who provided care on average matched the caring hours of their husbands. This confirms Horowitz's (1985b) observation that sons rely more than daughters on their spouses for parent care and extends her result to the British case.

The child-in-law's share of total care hours varied little between couples who provided large or small amounts of care; on average, sons-in-law provided $3^{8}$ per cent of the couple's caring hours and daughters-in-law 49 per cent whatever their total care hours. These findings support neither of the two patterns suggested in $\mathrm{H}_{3}$ a and $\mathrm{H}_{3} \mathrm{~b}$. Ideally, one needs longitudinal data to test the hypotheses, as the stable ratio between husband's and wife's caring can result from a mixture of different patterns. If taken at face value, however, the stability of the child-in-law's share of care-giving suggests a third pattern where couples agree a certain distribution of caring between them to which they adhere even if their caring hours increase.

Arber and Ginn's critical view of married men's caring that was referred to in the introduction does not reflect the care-giving for their parents of the majority of married men as most provided the larger part of the care that the couple provided. A small but important exception were the couples that provided personal care for the husband's mother. The relatively low number that cared for the husband's parents suggests that married men leave a lot of care for their parents to other family members, presumably their sisters.

The study found an interesting difference between sons-in-laws' and daughters-in-laws' hours of caring. The hours of a son-in-law depended only on his wife's hours and not on the number of different tasks that the 
couple provided, whereas the daughter-in-law's care depended both on her husband's hours and the parent's care needs. One could interpret this difference in the following way: sons-in-law are motivated by the wives' contributions but not by the parents' needs whereas daughters-in-law take both aspects into account. This supports Gerstel and Gallagher's (200I) notion that men are 'drawn into caring' by their wives, and it suggests that daughters-in-law often take a direct responsibility for the care of their parents-in-law in contrast to many sons-in-law. The findings about son-inlaws' care-giving correspond to the description of spouses as secondary helpers by Tennstedt, McKinlay and Sullivan (I989), but this, does not necessarily apply to daughters-in-law. The research from Tennstedt's team was based on the concept of the 'primary care-giver'. If one defines the primary care-giver as the carer who provided most hours of care, it could be that, regarding his parents, neither husband nor wife was a primary care-giver. If one of them was a primary carer, it was most likely the husband because in the majority of cases he provided more hours of care for his parents than did his wife. However, because daughters-in-law nearly matched their husband's hours of care, it does not seem appropriate to describe their contribution as secondary help. It is possible that the cases of informal caring for husbands' parents did not emerge strongly in the work of Tennstedt's team because they did not distinguish between care-giving for the husband's and the wife's parents, so that caring patterns for her parents might have dominated their results.

\section{Reasons for the division of parent care}

The study has discussed four potential key factors that influence a couple's division of parent care: paid work, care-recipients' preferences, coresidence with the parent, and gender roles. Past studies have identified men's employment as a buffer that allows them to limit their caring. This study supports these findings for sons-in-law and also finds that full-time employment is associated with lower levels of care-giving by daughtersin-law, supporting $\mathrm{H}_{4}$ a. It is tempting to interpret the result for women as a sign of changing gender roles where own employment becomes a legitimate excuse for both men and women for not providing care, but this was not entirely true - more women than men were not in the labour market and might have left the labour market in response to care demands (Henz 2006). However, the study shows that women who combine work and caring provided relatively low levels of care.

When examining the interdependence of children-in-laws' caring and their spouses' hours of paid work, we find that sons-in-law were most likely to be involved in care-giving if their wives worked full-time. In terms of 
hours, sons-in-law who were involved in caring provided more care if their wives were working for pay than otherwise. One can conclude that those women who combined full-time work and care-giving for their parents did this with their husband's support. One can also take the findings as an indicator that men's employment alone was not a legitimate excuse if their wives were working full-time. Whereas these results support $\mathrm{H}_{4} \mathrm{~b}$, daughters-in-law's involvement did not vary with their husband's employment. The difference between the caring of sons-in-law and daughtersin-law can be interpreted as further evidence for different approaches to caring: whereas sons-in-laws' caring depended on their wives' behaviour, daughters-in-law seemed to take more direct responsibility for the care of their parents-in-law.

The patterns associated with women's part-time work are ambiguous and can best be understood as resulting from two types of part-time working women: those who would have liked to work full-time but could not do so because of time restrictions, and those who enjoyed more leisure time. The first group of part-time working women could be those who obtained the same support with caring from their spouses as full-time working women and who made similarly low contributions to the care of their parents-in-law as full-time working women; the second group could be those women who had less support from their spouses with the care of their parents.

Another factor that strongly affected the involvement of children-in-law in parent care was the parent's co-residence, which was associated with a higher level of caring, supporting $\mathrm{H}_{5}$. Only for women's fathers was the effect not statistically significant. This resulted not only from the few cases for there is some indication that the wives' co-resident fathers were in better health than other co-resident parents. ${ }^{6}$ It might be that these men lived with the couple not because of their frailty but because they were not able to run their own home after their wives' death. This argument is supported by findings from Dale, Evandrou and Arber (1987) that elderly widowed men were more likely to live with their married children than elderly widowed women.

In addition, the preferences of the care-recipient might have influenced the couples' division of care. Because the data do not include any direct measures of preferences, the hypotheses could only be tested indirectly. Despite the gendered pattern of care-giving one cannot say that couples' caring predominantly followed gender lines because there was a strong consanguinal pattern in parent care, with the child being more frequently involved and providing the same or longer hours of care than the child-inlaw. An exception to the consanguinal pattern was personal care and, to a lesser extent, physical care. For these tasks, caring for the wife's parents 
followed a consanguinal pattern whereas caring for the husband's parents displayed a same-sex pattern. From this one can derive a hierarchy of parent carers, with daughters ranking first followed by same-sex patterns involving sons and daughters-in-law, thus refuting both $\mathrm{H}_{2} \mathrm{a}$ and $\mathrm{H}_{2} \mathrm{~b}$. For all other tasks, the parents of both sexes were treated similarly.

Finally, we find different patterns of involvement in parent care by men and women even after controlling for a number of factors, emphasising how informal caring varies with social norms and cultural contexts. Gender roles are only one example of the normative and cultural framing of care-giving (Aboderin 2004); further differences might be found between different ethnic groups (Peek, Coward and Peek 2000). Indeed, the $5^{2}$ couples in the sample with at least one spouse from an ethnic minority displayed a different overall pattern of care and care division: they provided care to fathers less often, the husband cared less often by himself for his parents; and the wife cared more often by herself for her parents. The differences could result partly from structural differences and partly from different family and gender norms.

Regarding the question of whether sons-in-law or daughters-in-law provided more care, the study shows that fewer daughters-in-law cared for their parents-in-law, but those who cared provided more hours of care than did sons-in-law. The 630 care-giving wives in the sample provided a total of 7,289 hours of care for their parents-in-law compared to 6,434 hours provided by the 702 caring sons-in-law. Therefore, daughters-in-law provided more care, but the difference was not large.

\section{Limitations and outlook}

The weaknesses of the study include the lack of information about parents' overall care needs and about other sources of care for the parent including parents' spouses, other adult children or relatives, and formal care providers. There is also no information about the quality of the relationship between care-receivers and their children-in-law, which Matthews (1998) has identified as a crucial factor for children-in-laws' caring. In addition, the study ignores other ways in which a couple can co-operate to accommodate caring for a parent, for example by relieving the carer from other household duties. The analysis relies on self-reported caring activities. Although this has clear advantages compared to indirect reporting, it might be open to different interpretations by the respondents, in a similar way to discrepancies about self-reported housework that have been observed (Kamo 2000; Lee and Waite 2005; Marini and Shelton I993).

It is also important to keep in mind that the analysis was based on crosssectional data. The positive effects of the wife's full-time employment on 
her husband's involvement in caring for her parents means that those women who managed to combine full-time employment with care-giving were more likely to have the support of their husbands. Other full-time working women who did not obtain this support might have lowered their working hours or left the labour market (Henz 2004). The conflict between paid work and caring is likely to intensify in the future. Women's economic activity rate is expected to rise further (Madouros 2006), which is crucial to safeguard women's pensions in the future (Price 2006). Despite rising female labour-market participation rates, current levels of informal care by married couples could be sustained if men increased their caregiving to the same extent as women might reduce it, but paid work also limits men's involvement in informal care. Both men and women should profit from policy measures to support working carers (Arksey 2002; Fredriksen-Goldsen and Scharlach 200 ; Phillips 2002), but although such policies might make huge differences to care-giver stress, their effects on the overall care-giving capacity of paid workers might be small (Henz 2006). If flexible working conditions are insufficient, the conflict between informal-care and paid-work might lead to a change in the culture of caregiving, with changes in perceptions of filial responsibility, and employed carers limiting their amount of hands-on caring.

Not just paid work but also cultural and demographic changes in families will affect the future care-giving of married children and their spouses. According to recent population projections, fewer people will be legally married, but in mid-age most of the reduction will be compensated by increased cohabitation (Office for National Statistics 2005). This will lower the care provided by children's spouses because the study has revealed a lower level of involvement of cohabiting spouses in the care of their parents-in-law. Recent research has also demonstrated the importance of divorce for intergenerational relationships both as it affects elderly parents (Glaser et al. 2006; Kalmijn 2007) and affects children (Brody et al. I995; Dooghe I992; Grundy I995). There is a risk that divorce and remarriage will lead to less caring by children-in-law, but it is up to future research to test this presumption. Finally, if current trends in living arrangements continue, fewer married couples will be living with a parent (Grundy 2000), which will entail a drop in the strong involvement of children-in-law in care-giving under such circumstances. A decline in co-resident intensive care by children for their parents has already been observed (Pickard 2002).

Projections of future care needs predict a strong increase in the demand for informal care provided by children over the next 20 years (Pickard et al. 2007). Over this period, the share of older people with surviving children is expected to increase (Murphy and Grundy 2003). The anticipated 
trends - women's increasing labour-force participation, less co-residence of parents with married children, increasing non-marital cohabitation, and possibly also higher levels of divorce and re-partnering - will weaken informal caring by children-in-law. For lack of other caring resources it seems likely that in the future caring for parents will increasingly rely on a successful co-operation of informal and formal care services.

\section{Acknowledgements}

The General Household Surveys were carried out by the Social Survey Division of the Office for National Statistics, formerly the Office of Population Censuses and Surveys. They were funded by British government departments and agencies. All data have been accessed through the UK Data Archive at the University of Essex. I thank Colin Mills for very helpful editorial advice.

\section{NOTES}

I The questions asked about the time spent 'on average each week' looking after or helping the care-recipient (I985 and I990 surveys) or about the time spent 'each week' looking after or helping the care-recipient (I995 and 2000 surveys).

2 It does not mean that men's parents received less care overall because many had other children who provided care and this needs to be kept in mind when reading what follows.

3 As the distribution in Table 4 could depend on the different tasks that entered the analysis, the frequencies were re-calculated without the two lightest tasks - keeping an eye on the parent and keeping the parent company. This resulted in only small changes, most notably a slight increase of between one and three percentage points in the proportion of couples who shared all tasks or all tasks but one.

4 The precise effect is that for every ro hours of his wife's care the husband increased his care hours by 2.7 hours (I62 minutes). This results in an effect of about a quarter of an hour per hour cared by the daughter.

5 The precise effect is that for every io hours of care by the husband, the wife cared for about five hours.

6 The healthiest quarter of the husbands' co-resident mothers-in-law received on average each about 25 hours of care per week from the couple whereas the healthiest quarter of the husbands' co-resident fathers-in-law received on average each only about ro hours of care from the couple. The corresponding hours for the healthiest quarters of the husband's co-resident parents are 30 hours of care received by fathers and 22.5 hours of care received by mothers.

\section{References}

Aboderin, I. 2004. Modernisation and ageing theory revisited: current explanations of recent developing world and historical Western shifts in material family support for older people. Ageing E̊ Society, 24, I, 29-50.

Arber, S. and Ginn, J. I991. Gender and Later Life. Sage, London. 
Arber, S. and Ginn, J. I995a. Gender differences in informal caring. Health and Social Care in the Community, 3, I9-3I.

Arber, S. and Ginn, J. I995 b. Gender differences in the relationship between paid employment and informal care. Work, Employment and Society, 9, 445-7I.

Arksey, H. 2002. Combining informal care and work: supporting carers in the workplace. Health and Social Care in the Community, Io, I5I-6I.

Brody, E. M., Litvin, S. J., Hoffman, C. and Kleban, M. H. I995. Marital status of caregiving daughters and co-residence with dependent parents. The Gerontologist, 35, 75-85.

Brody, E. M. and Schoonover, C. B. I986. Patterns of parent-care when adult daughters work and when they do not. The Gerontologist, 26, 372-8I.

Dale, A., Evandrou, M. and Arber, S. 1987. The household structure of the elderly population in Britain. Ageing \& Society, 7, 37-56.

Dautzenberg, M. G. H., Diederiks, J. P. M., Philipsen, H., Stevens, F. C. J., Tan, F. E. S. and Vernooij-Dassen, M.J. F.J. 200o. The competing demands of paid work and parent care. Research on Aging, 22, I65-87. $^{-8}$.

Dooghe, G. 1992. Informal care-givers of elderly people: an European review. Ageing \& Society, 1 2, 369-80.

Doty, P., Jackson, M. E. and Crown, W. 1998. The impact of female care-givers' employment status on patterns of formal and informal eldercare. The Gerontologist, 38, $33^{\mathrm{I}-4}$ I.

Dwyer, J. W. and Coward, R. T. I991. A multivariate comparison of the involvement of adult sons versus daughters in the care of impaired parents. Fournal of Gerontology: Social Sciences, 46, S259-69.

Dwyer, J. W. and Seccombe, K. I99I. Elder care as family labor: the influence of gender and family position. Fournal of Family Issues, $\mathbf{1} 2,229-47$.

Falkingham, J. and Grundy, E. 2006. Demographic Aspects of Population Ageing. ESRC Seminar Series: Mapping the Public Policy Landscape. Economic and Social Research Council, Swindon. Available online at http://esrcsocietytoday.esrc.ac.uk/ESRCInfoCentre/ Images/ESRC_population_ageing_doc_tcm6-I57I4.pdf [Accessed 22 April, 2008].

Finch, J. 1989. Family Obligations and Social Change. Blackwell, Oxford.

Fredriksen-Goldsen, K. I. and Scharlach, A. E. 200I. Families and Work. New Directions in the Twenty-First Century. Oxford University Press, New York.

Gerstel, N. and Gallagher, S. K. 200I. Men's caregiving: gender and the contingent character of care. Gender and Society, I 5, I97-217.

Glaser, K., Tomassini, C., Racioppi, F. and Stuchbury, R. 2006. Marital disruptions and loss of support in later life: a longitudinal study of the United Kingdom. European fournal of Ageing, 3, 207-I6.

Graham, H. 1983. Caring: a labour of love. In Finch, J and Groves, D. (eds), A Labour of Love: Women, Work and Caring. Routledge and Kegan Paul, London, I3-30.

Grundy, E. 1992. The living arrangements of elderly people. Reviewes of Clinical Gerontology, 2, $353-6$ I.

Grundy, E. 1995. Demographic influences on the future of family care. In Allen, I and Perkins, E. (eds), The Future of Family Care for Older People. Her Majesty's Stationery Office, London, I-I7.

Grundy, E. 2000. Co-residence of mid-life children with their elderly parents in England and Wales: changes between rg8i and i991. Population Studies, 54, I93-206.

Henz, U. 2004. The effects of informal care on paid-work participation in Great Britain: a lifecourse perspective. Ageing $\&$ Society, 24, 85 I-80.

Henz, U. 2006. Informal caregiving at working age: effects of job characteristics and family configuration. Fournal of Marriage and Family, 68, $4 \mathrm{I}$-29.

Hequembourg, A. and Brallier, S. 2005. Gendered stories of parental caregiving among siblings. Fournal of Aging Studies, r 9, 53-71. 
Hirst, M. 200I. Trends in informal care in Great Britain during the 1990. Health and Social Care in the Community, 9, 348-57.

Horowitz, A. I985a. Family caregiving to the frail elderly. In Lawton, M.P and Maddox, G. L. (eds), Annual Review of Gerontology and Geriatrics, Volume 5. Springer, New York, I94-245.

Horowitz, A. $1985 b$. Sons and daughters as care-givers to older parents: differences in role performance and consequences. The Gerontologist, 25, 612-17.

Ingersoll-Dayton, B., Starrels, M. E. and Dowler, D. I996. Caregiving for parents and parents-in-law: is gender important? The Gerontologist, 36, 483-9I.

Johnson, R. W. and Lo Sasso, A. T. 2000. The trade-off between hours of paid employment and time assistance to elderly parents at midlife. Washington, DC: Urban Institute. Available online at: http://www.urban.org/expert.cfm?ID=Anthony TLoSasso [Accessed 7 August 2008].

Kalmijn, M. 2007. Gender differences in the effects of divorce, widowhood and remarriage on intergenerational support: does marriage protect fathers? Social Forces, 85, I079-I04.

Kamo, Y. 2000. "He said, she said": assessing discrepancies in husbands' and wives" reports on the division of household labor. Social Science Research, 29, 459-76.

Keating, N., Otfinowski, P., Wenger, C., Fast, J. and Derksen, L. 2003. Understanding the caring capacity of informal networks of frail seniors: a case for care networks. Ageing $\mathcal{E}^{\circ}$ Society, 23, II $15-27$.

Kivett, V. R. I985. Consanguinity and kin level: their relative importance to the helping network of older adults. Fournal of Gerontology, 4o, 228-34.

Lee, E., Spitze, G. and Logan, J. R. 2003. Social support to parents-in-law: the interplay of gender and kin hierarchies. Fournal of Marriage and Family, 65, 396-403.

Lee, G. R., Dwyer, J. W. and Coward, R. T. i993. Gender differences in parent care: demographic factors and same-gender preferences. Fournal of Gerontolgy: Social Sciences, $\mathbf{4 8}$, S9-16.

Lee, Y. S. and Waite, L. J. 2005. Husbands' and wives' time spent on housework: a comparison of measures. Fournal of Marriage and Family, 67, 328-36.

Litwak, E. I985. Helping the Elderly. Guildford Press, New York.

Madouros, V. 2006. Projections of the UK labour force, 2006-2020. Labour Market Trends, I I 4, I3-27.

Marini, M. M. and Shelton, B. A. I993. Measuring household work: recent experiences in the United States. Social Scence Research, 22, 36I-82.

Matthews, S. H. I995. Gender and the division of filial responsibility between lone sisters and their brothers. Fournal of Gerontology: Social Sciences, 5oB, S312-20.

Matthews, S. H. I998. Meeting filial responsibilities in brothers-only sibling groups. Fournal of Gerontology: Social Sciences, 53B, S278-86.

Murphy, M. and Grundy, E. 2003. Mothers with living children and children with living mothers: the role of fertility and mortality in the period I9I-2050. Population Trends, I I 2, 36- 44 .

Office for National Statistics. 1998. Informal Carers. Stationery Office, London.

Office for National Statistics, Social Survey Division. 2000. General Household Survey, 2000-200I [computer file]. Colchester, Essex: UK Data Archive [distributor], I6 July 2002. SN: $45 \mathrm{I} 8$.

Office for National Statistics. 2002. Carers 200o. Stationery Office, London.

Office for National Statistics. 2005. 2003-based martial status and cohabitation projections for England and Wales. Population Trends, I 21, $77^{-84}$.

Office of Population Censuses and Surveys, Social Survey Division. I985, I990 \& 1995. General Household Survey, 1985, 1990-1991, 1995-1996 [computer files]. Colchester, Essex: UK Data Archive [distributor], 6 April ig88. SN: 2349; 6 October 1992. SN: 2937; June 1998. SN: 369o. 
Parker, G. 1990. With Due Care and Attention: A Review of Research on Informal Care. Second edition, Family Policy Studies Centre, London.

Peek, M. K., Coward, R. T. and Peek, C. W. 200o. Race, aging, and care. Research on Aging, 22, II7-42.

Penrod, J. D., Kane, R. A., Kane, R. L. and Finch, M. D. 1995. Who cares? The size, scope, and composition of the care-giver support system. The Gerontologist, 35, 489-97.

Phillips, J., Bernard, M. and Chittenden, M. 2002. Juggling Work and Care: The Experiences of Working Carers of Older People. Policy Press, Bristol, UK.

Pickard, L. 2002. The decline of intensive intergenerational care of older people in Great Britain, I985-I995. Population Trends, I Io, 31-4I.

Pickard, L., Wittenberg, R., Comas-Herrera, A., King, D. and Malley, J. 2007. Care by spouses, care by children: projections of informal care for older people in England to 2031. Social Policy and Society, 6, 353-66.

Pillemer, K. and Suitor, J. J. 2006. Making choices: a within-family study of care-giver Selection. The Gerontologist, 46, 439-48.

Price, D. 2006. Gender and generational continuity: breadwinners, care-givers and pension provision in the UK. International Fournal of Ageing and Later Life, I, $3{ }^{\mathrm{I}-66 .}$

Qureshi, H. and Walker, A. I989. The Caring Relationship: Elderly People and Their Families. Macmillan, Basingstoke, Hampshire, UK.

Scott, A. and Wenger, G. C. I995. Gender and social support networks in later life. In Arber, S and Ginn, J. (eds), Connecting Gender and Ageing. A Sociologial Approach. Open Univeresity Press, Buckingham, $158-72$.

Shanas, E. I979. The family as a social support system in old age. The Gerontologist, r 9, I69-74.

Shuey, K. and Hardy, M. A. 2003. Assistance to aging parents and parents-in-law: does lineage affect family allocation decisions? Fournal of Marriage and Family, 65, 418-31.

Soldo, B. J., Wolf, D. A. and Agree, E. M. ig9o. Family, households, and care arrangements of frail older women: a structural analysis. Fournal of Gerontology : Social Sciences, 45, S238-49.

Spitze, G. and Logan, J. I99o. Sons, daughters, and intergenerational social support. Fournal of Marriage and the Family, 52, 420-30.

Stoller, E. P. 1983. Parental caregiving by adult children. Fournal of Marriage and the Family, $45,85 \mathrm{I}-8$.

Stoller, E. P. I990. Males as helpers: the role of sons, relatives, and friends. The Gerontologist, 30, 228-35.

Stone, R., Cafferata, G. L. and Sangl, J. 1987. Care-givers of the frail elderly: a national profile. The Gerontologist, 27, 616-26.

Tennstedt, S. L., Crawford, S. and McKinlay, J. B. I99I. Determining the pattern of community care: is coresidence more important than care-giver relationship? Fournal of Gerontology: Social Sciences, 48, S73-83.

Tennstedt, S. L., McKinlay, J. B. and Sullivan, L. M. I989. Informal care for frail elders: the role of secondary care-givers. The Gerontologist, 29, 677-83.

Ungerson, C. I987. The life course and informal caring: towards a typology. In Cohen, G. (ed.), Social Change and the Life Course. Tavistock, London, I84-208.

Accepted 15 August 2008

Address for correspondence:

Ursula Henz, Department of Sociology,

London School of Economics, Houghton Street, London $\mathrm{WC}_{2} \mathrm{~A}_{2} \mathrm{AE}$.

Email: u.henz@lse.ac.uk 